УДК 340.15

DOI: https://doi.org/10.32631/pb.2020.4.14

ІРИНА ОЛЕКСАНДРІВНА СТОРОЖЕНКО,

Харківський національний університет внутрішніх справ;

https://orcid.org/0000-0003-2747-5455,

e-mail: storozchenko@meta.ua

\title{
СИСТЕМА ОРГАНІВ ТА УСТАНОВ ІЗ ПОПЕРЕДЖЕННЯ І ПРОТИДІЇ ЗЛОЧИННОСТІ НЕПОВНОЛІТНІХ ОСІБ (НА МАТЕРІАЛАХ УКРАЇНСЬКИХ ГУБЕРНІЙ У СКЛАДІ РОСІЙСЬКОЇ ІМПЕРІЇ)
}

\begin{abstract}
Досліджено функціональні особливості та правовий статус системи органів та установ із попередження і протидії злочинності неповнолітніх осіб на матеріалах українських губерній у складі Російської імперії. Проаналізовано та виокремлено особливості завдань і компетенції окремих органів та установ, діяльність яких була так чи інакше пов'язана із протидією злочинності неповнолітніх. Особливу увагу в зазначеному контексті приділено Міністерству внутрішніх справ, а також функціонуванню благодійних установ та організацій.
\end{abstract}

Ключові слова: неповнолітні, неповнолітні злочинці, кримінальна відповідальність, злочинність, протидія злочинності, суб'єкт злочину, попередження злочинів.

Оригінальна стаття

\section{Постановка проблеми}

Особливої значущості в контексті становлення демократичної і правової держави набуває проблема попередження та боротьби зі злочинністю неповнолітніх осіб, яка досить гостро постає в аспекті наближення вітчизняного законодавства до стандартів Європейського Союзу. Злочинні прояви серед неповнолітніх осіб є, мабуть, одними з найбільш домінуючих проявів криміногенної активності. У зв'язку із цим одним із пріоритетних завдань кримінальної політики у сфері попередження і протидії злочинності стає визначення сутності цього явища, аналіз причин та умов, які йому сприяють, а також інших концептуальних характеристик. Саме в контексті активної боротьби із суспільно небезпечними протиправними проявами й елементами, які суперечать моральним засадам суспільства, що прямо та опосередковано виникають унаслідок злочинної діяльності неповнолітніх, особливо цінним $\epsilon$ аналогічний досвід, накопичений в інших хронологічних межах становлення українського державотворення. Аналіз основних напрямків діяльності окремих органів та установ 3 метою підтримання законності та правопорядку дозволяє не лише вивчити й узагальнити накопичений досвід, але й виробити практичні рекомендації, що стосуються перспектив і дієвих векторів протидії злочинності.

Вивчення історико-правових аспектів боротьби з кримінальними правопорушеннями, що вчиняються неповнолітніми, має важливе значення для визначення загальних законо- мірностей розвитку цього явища, а також для покращення та оптимізації організаційноправових засад діяльності органів, діяльність яких пов'язана з попередженням і припиненням правопорушень з боку неповнолітніх осіб.

\section{Стан дослідження проблеми}

Питання, пов'язані з вивченням на науковому рівні проблем становлення і розвитку системи органів та установ із попередження та протидії злочинності неповнолітніх осіб, привертали увагу багатьох учених, серед яких О. М. Бандурка, Ю. В. Баулін, В. М. Бородін, В. М. Бурдін, В. О. Глушков, Н. Ф. Кузнецова, В. О. Навроцький, В. В. Сташис та ін. Визначальні фундаментальні аспекти в контексті кримінальної відповідальності неповнолітніх осіб були закладені такими відомими вченимиправниками, як О. М. Богдановський, Л. М. Василевський, О. Ф. Кистяковський і М. С. Таганцев. Водночас, попри сталу цікавість науковців до вказаної проблематики, опрацювання та виокремлення особливостей кримінальної відповідальності неповнолітніх осіб і попередження злочинності в їх історико-правовому осяганні, особливо на матеріалах українських губерній у складі Російської імперії, належить до малодосліджених тем.

\section{Мета і завдання дослідження}

Метою статі є комплексне та доктринальне дослідження функціональних особливостей і правового статусу системи органів та установ із попередження і протидії злочинності 
неповнолітніх осіб на матеріалах українських губерній у складі Російської імперії.

Зважаючи на сформульовану мету, завданнями статті $є$ аналіз і виокремлення системи органів та установ, діяльність яких була спрямована на попередження і протидію злочинності неповнолітніх осіб.

Наукова новизна дослідження полягає в тому, що ця стаття $\epsilon$ першою науковою працею, в якій проаналізовано правовий статус системи органів та установ із попередження і протидії злочинності неповнолітніх осіб на матеріалах українських губерній у складі Російської імперії.

\section{Виклад основного матеріалу}

Початок реалізації заходів у сфері піклування про бідних, а разом із тим і надання допомоги та підтримки соціально знедоленим дітям і підліткам припадає на кінець XVII ст., коли влада усвідомила необхідність свого втручання у справи бідних, однак державний вплив мав епізодичний характер. Законодавчо лише у XVIII ст. було ухвалено наказ про створення спеціалізованих органів - приказів громадського піклування, діяльність яких була спрямована на організацію та надання соціальної допомоги нужденним дітям і підліткам, піклування про неповнолітніх сиріт тощо.

Маніфестом імператора Олександра I «Про заснування міністерств» від 8 вересня 1802 р. було створено Міністерство, що мало вісім відділень, а особи, які їх очолювали, вважалися міністрами. У контексті нашого дослідження особливої уваги заслуговує відділення внутрішніх справ, до складу якого належали експедиції, діяльність яких мала бути спрямована на виконання статутних завдань. Особливий інтерес становить діяльність Четвертої експедиції, що пов'язано перш за все з переходом в її підпорядкування повноважень з вирішення всіх питань піклування про бідних, серед іншого - малолітніх і неповнолітніх правопорушників, а також інших дітей та підлітків, які потребували допомоги [1, с. 13-15].

Усвідомлення необхідності збільшення державної присутності у сфері піклування про бідних, особливо про дітей і підлітків, з метою посилення, перш за все профілактичного впливу на них і недопущення збільшення кількості правопорушників-дітей як найбільш криміногенної частини суспільства сприяло активізації діяльності відомства в цьому напрямку. Усі структурні підрозділи, які прямо чи опосередковано займалися благодійною діяльністю, можна поділити на такі групи, як навчально-виховні, лікувальні, богадільні, робітні та виправні. Першочергово державні кошти спрямовувалися на утримання навчальновиховних будинків, але відсутність належного санітарно-гігієнічного утримання цих установ призводила до високої смертності осіб, які в них перебували. Ситуацію погіршували часті випадки шахрайства з боку селян, які під виглядом незаконнонароджених приносили своїх дітей, а потім брали їх на утримання з одночасним одержанням грошових коштів на їх виховання. У зв'язку з цим проведена у 1828 р. перевірка діяльності таких закладів засвідчила очевидну неефективність відкриття нових виховних будинків, а в наявні установи було ухвалено рішення приймати тільки дітей, підібраних поліцією, і тих, які не мають батьків. У богадільні громадського піклування, як правило, поміщали неповнолітніх, які не досягли 17річного віку і через каліцтва або з інших причин за станом здоров'я не могли бути придатними до селянських або інших робіт [2, с. 16].

В юридичній літературі існувала думка про те, що поліцейська діяльність держави має своїм завданням, з одного боку, попередження дій, що порушують громадський порядок, а з іншого - сприяння подальшому розвитку народного добробуту [3, с. 84]. Із цього погляду істотною була та обставина, що саме на органи поліції покладалися завдання 3 морально-психологічного виховання неповнолітніх осіб. Необхідно зауважити, що діяльність поліції в зазначений період була досить всеохопною $\mathrm{i}$ різноманітною. Особлива увага з боку поліцейських органів приділялася таким проблемам, як жебрацтво, бродяжництво і проституція, особливо якщо ці правопорушення і злочини вчинялися неповнолітніми особами [4, с. 230].

Бродяжництво та жебракування як соціально-економічні явища, особливо серед неповнолітніх, завжди становили проблему для держави, будучи латентними, прихованими факторами злочинності й негативно позначаючись на формуванні особистості неповнолітніх. У 1838 р. спеціальним наказом було встановлено класифікацію жебраків із поділом їх на три категорії. До першої були віднесені всі ті, хто набув такого статусу через нещасні обставини (сирітство, стан здоров'я тощо), до другої - особи, які стали жебраками через лінощі або іншу особисту звичку до праці чи ремесла, внаслідок чого підлягали виселенню до Сибіру чи на казенні фабрики; до третьої особи, які набули такого статусу тимчасово 3за певних обставин [5, с. 12-14].

Соціальний напрямок діяльності перш за все був пов'язаний із виправленням 
неповнолітніх правопорушників і просто нещасних дітей, які опинилися в скрутному становищі через певні життєві обставини, а також безхатченків, яким загрожувала небезпека стати злочинцями. За допомогою різних благодійних закладів, зокрема утримання в них неповнолітніх, діяльність правоохоронних осіб у цій сфері була спрямована на забезпечення виховання і навчання, щоби підлітки змогли стати корисними суспільству громадянами.

Отже, можна зробити висновок, що діяльність Міністерства була пов'язана насамперед із розробленням та ухваленням різних нормативно-правових актів (інструкцій, циркулярів, постанов, наказів), спрямованих на протидію та запобігання правопорушенням, які вчиняються неповнолітніми, а також у сфері піклування щодо дітей і підлітків, у тому числі у сфері боротьби з жебрацтвом, бродяжництвом і проституцією неповнолітніх як із найбільш поширеними соціально небезпечними явищами. Формально-правовий характер цієї діяльності був пов'язаний із затвердженням та погодженням статутів, положень благодійних установ і товариств із метою недопущення суперечності їх діяльності чинному законодавству, а також основних концепцій державної політики в зазначеній сфері. Крім того, кримінально-адміністративний вектор діяльності правоохоронних органів був спрямований на реалізацію комплексу заходів із боротьби $з$ правопорушеннями неповнолітніх, у тому числі супутніми їм явищами кримінального характеру. Водночас заходи з упорядкування структури та функціональних обов'язків окремих службових і посадових осіб приказів громадського піклування 3 метою оптимізації їх роботи можна вважати організаційно-штатним напрямком у діяльності Мiністерства внутрішніх справ.

Дитяча злочинність $\epsilon$ пов'язаною з усіма сторонами суспільного та державного життя з одними - прямо, з іншими - опосередковано, однак незалежно від їх ролі на всезагальному рівні мають бути створені такі умови та відносини, які зможуть суттєво вплинути на зниження рівня дитячої злочинності. Саме з цією метою наприкінці XVIII ст. виникла ідея створення особливих закладів, діяльність яких мала спрямовуватися на утримання малолітніх злочинців. У Російській імперії перші заклади для малолітніх злочинців виникли у XIX ст., причому спочатку на території прибалтійських губерній, де був найбільшою мірою вираженим вплив Німеччини. За великим переконанням уряд сподівався, що саме в такий спосіб на території всієї імперії, як і в європей- ських державах, буде створена величезна система виправних притулків, які ліквідують дитячу злочинність узагалі [6, с. 39-40].

Першим спеціальним місцем виправлення малолітніх злочинців стало Санкт-Петербурзьке товариство землеробських колоній і ремісничих притулків, статут якого був затверджений 15 січня 1870 р. Згодом за його зразком було утворено Харківське товариство виправних притулків (1871р.), Київське товариство землеробських колоній та виправних притулків (1874р.) тощо [7, с. 11].

Усі колонії і притулки були засновані завдяки приватній ініціативі, оскільки урядових закладів не існувало. Виникали вони там, де були ініціатори, які цікавились долею і перевихованням неповнолітніх, або там, де склалося досить працездатне суспільство, тому такі заклади створювалися повільно і не завжди успішно. Діючі виправно-виховні заклади для неповнолітніх у більшості випадків утримувалися на кошти благодійних товариств приватного характеру. Щоб заохотити створення таких установ, уряд надавав такі пільги, як звільнення від будь-яких зборів і податків на майно, яке належало притулкам чи придбавалось ними, надання в разі необхідності земельних ділянок для користування, можливість проведення лотерей серед населення, в окремих випадках щомісячне надання плати на їжу й одяг на кожного неповнолітнього із сум, які виділялись на утримання арештантів, тощо. Водночас, попри те, що система таких гарантій і пільг була досить значною, їх розміру було все ж недостатньо для належного функціонування таких установ [8, с. 109].

Основними засобами виховання у виправних закладах для неповнолітніх правопорушників були релігійно-моральне виховання, праця, професійне навчання, елементарна освіта й система нагород і покарань. У цих закладах значна увага приділялась також естетичному i фізичному вихованню, а в багатьох - і військовим заняттям. Засоби морального виправлення спочатку визначалися статутами, але в подальшому були закріплені на загальнодержавному рівні відповідно до окремого положення, ухваленого в 1909 р. [9, с. 112-113].

Досвід роботи з виправлення і перевиховання неповнолітніх правопорушників підштовхнув фахівців до висновку, що правильно влаштована система виправлення неповнолітніх без організованого патронату $є$ недопустимою, при цьому під патронатом розумілася сукупність спеціальних заходів піклування над особами цієї категорії з метою відриву їх від злочинного середовища і ресоціалізації. 
Він мав такі особливості: патронат над неповнолітніми, які звільнилися з місць позбавлення волі, був для них обов'язковим, тоді як головною умовою здійснення патронату для дорослих було каяття в раніше скоєних злочинах (тобто враховувалася добровільність ухвалення рішення); патронат над неповнолітніми здійснювався протягом певного проміжку часу та як тимчасовий засіб.

У зв'язку з відсутністю необхідної і достатньої законодавчої бази, а також досвіду в діяльності та здійсненні патронату над неповнолітніми існували й різні погляди на його організацію, зокрема пропонувалися дві моделі його функціонування: перша - патронат повинен мати загальний характер, тобто поширюватися не лише на осіб, які звільняються 3 місць позбавлення волі та виховних закладів, а й на безпритульних, жебраків та інші категорії неповнолітніх; друга - патронат повинен бути спеціальним, тобто орієнтованим лише на неповнолітніх, які залишили виховні заклади [10, с. 28].

Необхідно зауважити, що організація патронату мала благодійницький характер і здійснювалася на громадських засадах, хоча цілі, поставлені перед ним, мали кримінально-політичне значення, оскільки передбачали боротьбу зі злочинністю. Патронат практично здійснювався трьома різновидами організацій: спеціальними товариствами патронату над неповнолітніми, самими виправно-виховними закладами для неповнолітніх або товариствами, які їх заснували, і товариствами тюремного патронату, які поширювали свою діяльність, серед іншого, і на неповнолітніх (наприклад, Київське). У розглядуваний період на всій території Російської імперії існувало 13 спеціальних товариств, створених для надання допомоги неповнолітнім, які звільня- ються з місць позбавлення волі, зокрема на українських територіях - у Києві, Харкові та Одесі. Головною метою товариств, що реалізовували зазначені функції, було сприяння неповнолітнім, які вийшли з виховних закладів i місць ув'язнення, в облаштуванні побуту і повернення їх до чесного і нормального життя.

\section{Висновки}

Можна зробити висновок, що діяльність Міністерства внутрішніх справ була пов'язана із розробленням та ухваленням різних нормативно-правових актів (інструкцій, циркулярів, постанов, наказів), спрямованих на протидію та запобігання правопорушенням, які вчиняються неповнолітніми, а також у сфері піклування про дітей і підлітків, зокрема у сфері боротьби 3 жебрацтвом, бродяжництвом i проституцією неповнолітніх як найбільш поширеними соціально небезпечними явищами, й у ній можна було виділити формальноправовий, кримінально-адміністративний та організаційно-штатний напрямки.

Підбиваючи підсумок дослідженню участі й ролі благодійних установ та організацій у період Російської імперії у сфері протидії та попередження злочинності неповнолітніх, слід зазначити, що приватна благодійність недержавних (неофіційних) громадських організацій і приватних осіб на межі XIX-XX ст. була досить поширеною, а їх діяльність охоплювала майже всі напрямки надання соціальної допомоги нужденним дітям і підліткам, причому допомога і підтримка надавалися досить широкому колу осіб переважно з метою створення умов, які мали не допускати подальшого розвитку і поширення правопорушень, що вчиняються неповнолітніми, та їх подальшої криміналізації.

\section{Список бібліографічних посилань}

1. Познышев С. В. Детская преступность и меры борьбы с нею. М., 1911. 69 с.

2. Беляева Л. И. Становление отечественной школы предупреждения преступлений несовершеннолетних. Вопросы ювенальной юстиции. 2007. № 3. С. 11-17.

3. Александровский Ю. В. Положение о воспитательно-исправительных заведениях для несовершеннолетних. СПб., 1909. 112 с.

4. Богдановский А. М. Молодые преступники - вопрос уголовного права и уголовной политики. СПб. : Тип. Моригеровского, 1871. 300 с.

5. Золотарев А. А. Личная и общественная борьба с развратом. М., 1897. 33 с.

6. Есипов В. В. Преступность и меры воздействия. Варшава : Тип. Варшавского учеб. округа, 1900. $280 \mathrm{c.}$

7. Кистяковский А. Ф. Молодые преступники и учреждения для их исправления, с обозрением русских учреждений. Киев : Унив. тип., 1878. 232 с.

8. Коротнев А. Д. Малолетние и несовершеннолетние преступники. СПб. : Труд, 1903. 115 с.

9. Духовской М. В. Распределение исправительных заведений по территории России. Журнал Министерства юстищии. 1900. № 7. С. 111-129. 
10. Тимофеев А. Попечительство над преступной и бесприютной молодежью. Тюремный вестник. 1894. № 9. С. 26-31.

Надійшла до редколегії 07.12.2020

\section{СТОРОЖЕНКО И. А. СИСТЕМА ОРГАНОВ И УЧРЕЖДЕНИЙ ПО ПРЕДУПРЕЖДЕНИЮ И ПРОТИВОДЕЙСТВИЮ ПРЕСТУПНОСТИ НЕСОВЕРШЕННОЛЕТНИХ ЛИЦ (НА МАТЕРИАЛАХ УКРАИНСКИХ ГУБЕРНИЙ В СОСТАВЕ РОССИЙСКОЙ ИМПЕРИИ)}

Исследованы функциональные особенности и правовой статус системы органов и учреждений по предупреждению и противодействию преступности несовершеннолетних лиц на материалах украинских губерний в составе Российской империи. Проведен анализ и выделены особенности задач и компетенции отдельных органов и учреждений, деятельность которых была так или иначе связана с противодействием преступности несовершеннолетних. Особое внимание в выбранном контексте уделено Министерству внутренних дел, а также функционированию благотворительных учреждений и организаций.

Ключевые слова: несовершеннолетние, несовершеннолетние преступники, уголовная ответственность, преступность, противодействие преступности, субъект преступления, предупреждение преступлений.

\section{STOROZHENKO I. O. SYSTEM OF AGENCIES AND INSTITUTIONS FOR PREVENTING AND COUNTERACTING JUVENILE DELINQUENCY (BASED ON THE MATERIALS OF THE UKRAINIAN PROVINCES AS PART OF THE RUSSIAN EMPIRE)}

The author has studied the functional features and the legal status of the system of agencies and institutions for the prevention and counteraction to juvenile delinquency based on the materials of the Ukrainian provinces as part of the Russian Empire.

The author has carried out analysis and has singled out specific features of the tasks and competences of certain agencies and institutions, which activity was in one way or another related to the counteraction to juvenile delinquency. Special attention in the chosen context has been paid to the Ministry of Internal Affairs, as well as to the functioning of charitable institutions and organizations.

The emphasis has been placed on the fact that the activities of the Ministry of Internal Affairs were related to the development and adoption of various regulatory acts (instructions, circulars, decrees, orders) aimed at counteracting and preventing offenses committed by juveniles, as well as in the field of custody of children and adolescents, including in the field of combating begging, vagrancy and prostitution of minors as the most common socially dangerous phenomena.

The participation and role of charitable institutions and organizations in the period of the Russian Empire in counteracting and preventing juvenile delinquency have been studied. It has been proved that private charity of non-governmental (informal) public organizations and individuals was very common on the cusp of the XIX and the XX centuries, and their activities covered almost all areas of social assistance to children and adolescents in need. Assistance and support was provided to a rather wide range of persons, mainly to create conditions that prevent the commission of juvenile delinquency and their further criminalization.

Key words: minors, juvenile offenders, criminal liability, crime, combating crime, subject of a crime, crime prevention. 